\title{
When climate change predictions are right for the wrong reasons
}

\author{
Wally Broecker ${ }^{1}$
}

Received: 5 October 2016 / Accepted: 12 February 2017 / Published online: 3 March 2017

C The Author(s) 2017. This article is published with open access at Springerlink.com

\begin{abstract}
Just over 40 years ago, I wrote a paper entitled "Climate change: Are we on the brink of a pronounced global warming?" In it, I attempted to explain why despite a rise in the atmosphere's CO2 content there had been no significant warming. I predicted that a natural cooling was about to give way to a warming, and that industrial emissions of $\mathrm{CO} 2$ would amplify this warming. The paper published in Science in 1975. Warming did follow in 19761977. However, a retrospective look shows that my analysis was flawed. What is more - and to my chagrin - based on the words "global warming" in my Science paper, I was given the title "Father of Global Warming." Not only did I not like this title, I had done little to merit it.
\end{abstract}

\section{Dumb luck}

My Science paper made use of the oxygen isotope record from the northern Greenland Camp Century ice core, the only available well-dated and highly detailed record. The oxygen isotope record was thought to serve as a proxy for local air temperature. Willi Dansgaard, the pioneer of such studies, had shown that over the last 800 years, much of the variance in his ${ }^{18} \mathrm{O}$ record could be explained by a combination of 180- and 80-year cycles (Dansgaard et al. 1971).

Based on a forward extrapolation of these cycles, I proposed that a natural cooling was about to give way to a natural warming. So, instead of opposing a fossil fuel $\mathrm{CO}_{2}$-driven warming, nature would reinforce it. I submitted my paper to Science in March 1975 and it was published before the year's end (Broecker 1975). Lo and behold, a pronounced global warming which has now reached $0.9^{\circ} \mathrm{C}$ commenced in 1976-1977 (see Fig. 1).

However, over the next couple of decades, it became clear that my use of the Camp Century record as a stand-in for global temperature was flawed. As other records including those for ice cores from southern and central Greenland appeared, none showed Dansgaard's 180- and 80-

Wally Broecker

broecker@ldeo.columbia.edu

1 Lamont-Doherty Earth Observatory of Columbia University, 61 Route 9W, PO Box 1000, Palisades, NY 10964, USA 


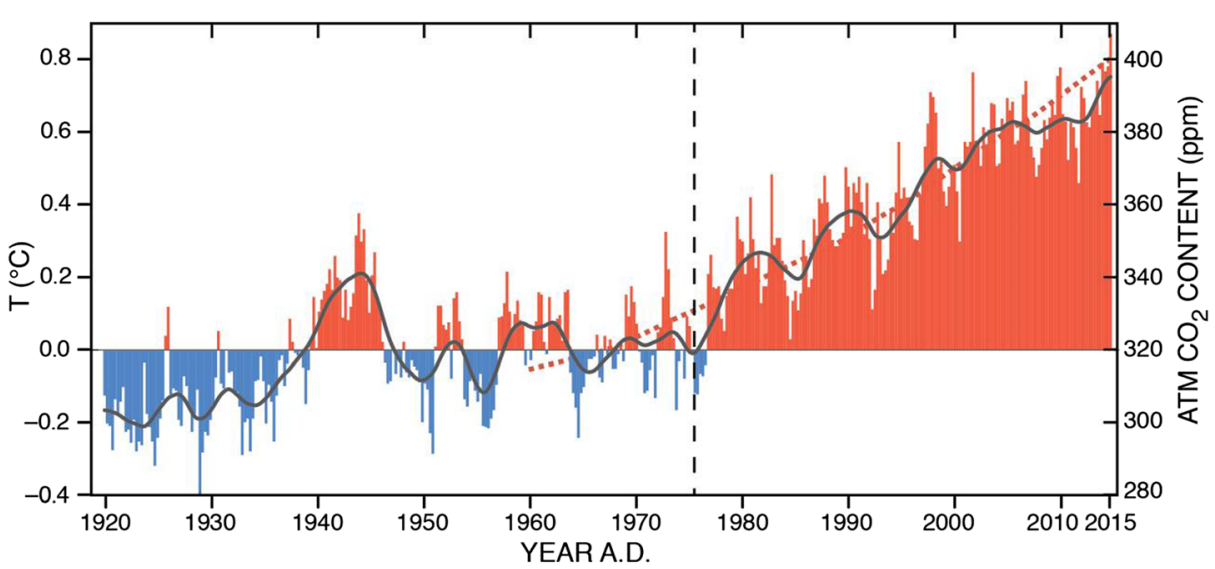

Fig. 1 The thermometric record of average earth temperature (Trenberth 2015) and the Mauna Loa $\mathrm{CO}_{2}$ record (red dotted line). Note what appears to be a 30-year-duration plateau in temperature extending from 1945 to 1975 A.D. It came to an end in 1976-1977, just after my Science paper was published (vertical dashed line)

year cycles. Because of this, I became convinced that my analysis was faulty and that my prediction, although correct, was the product of dumb luck.

\section{I am not the father!}

My Science paper circulated widely; given the paper's title, some popular media sites unfortunately started referring to me as the "Father of Global Warming." This credit was misplaced. If there has to be such a person, it should be the late Charles David Keeling, whose tireless work unequivocally demonstrated that atmospheric $\mathrm{CO}_{2}$ concentrations are rising in lock-step with fossil fuel use.

In 2001, I offered a \$200 reward to anyone who could find an earlier use of the two words "global warming." For a long time, I received no claim. But finally, one appeared. David McGee, then a colleague here at Lamont-Doherty, found a 3-in.-long column in Indiana's The Hammond Times (6 November 1957) which used these words. Its subject was a claim by unnamed scientists in Southern California that $\mathrm{CO}_{2}$ released by industry was going to lead to global warming. The 1957 date for this piece was close to the time when Keeling was gearing up for his $\mathrm{CO}_{2}$ measurements at the Mauna Loa Observatory on the island of Hawaii. I suspect the unnamed scientists were Keeling and Roger Revelle, the director of Scripps.

I promptly gave David McGee the promised reward. Since then, other uses of "global warming" prior to my 1975 publication have come to my attention. Two scientific papers in the 1960s used the phrase, one by. JM Mitchell in 1961 and the other by NR Malkin in 1968. It is my hope that the title "Father of Global Warming" does not appear on my tombstone. Were it to, I would be faced with a restless afterlife.

\section{What happened in 1976-1977?}

I only recently became aware of the broad similarity between the ${ }^{18} \mathrm{O}$ record in Greenland ice and that for the North Atlantic Oscillation (NAO) index. I was alerted to it by a paper authored 
by one of my colleagues at Lamont-Doherty (Young et al. 2015). In it was reproduced the NAO reconstruction for the last 400 years published by Trouet et al. (2009). In Fig. 2, I place it side by side with Dansgaard's Greenland ${ }^{18} \mathrm{O}$ record and that for the NAO index. While by no means identical to the Dansgaard record, the NAO record has humps and valleys of similar duration. These bumps and valleys are absent in the global temperature record. Likely Dansgaard's ${ }^{18} \mathrm{O}$ record was influenced by changes in the isotopic composition of snowfall perhaps related to the NAO. When I asked Scripps's Jeff Severinghaus about this, he pointed out that a decade ago, Vinther et al. (2003) had shown that the ${ }^{18} \mathrm{O}$ record in Greenland ice resembled that for the NAO. If so, it certainly cannot be used, as I did, as a proxy for global temperature. Yes, my prediction was dumb luck!

This leaves the question of what happened in 1976-1977. I am aware of a dramatic change that occurred at this time. It took place in the thermocline of the Pacific Ocean. Based on monthly records for ${ }^{14} \mathrm{C}$ to $\mathrm{C}$ ratio in a Galapagos coral and for sea surface temperatures in the

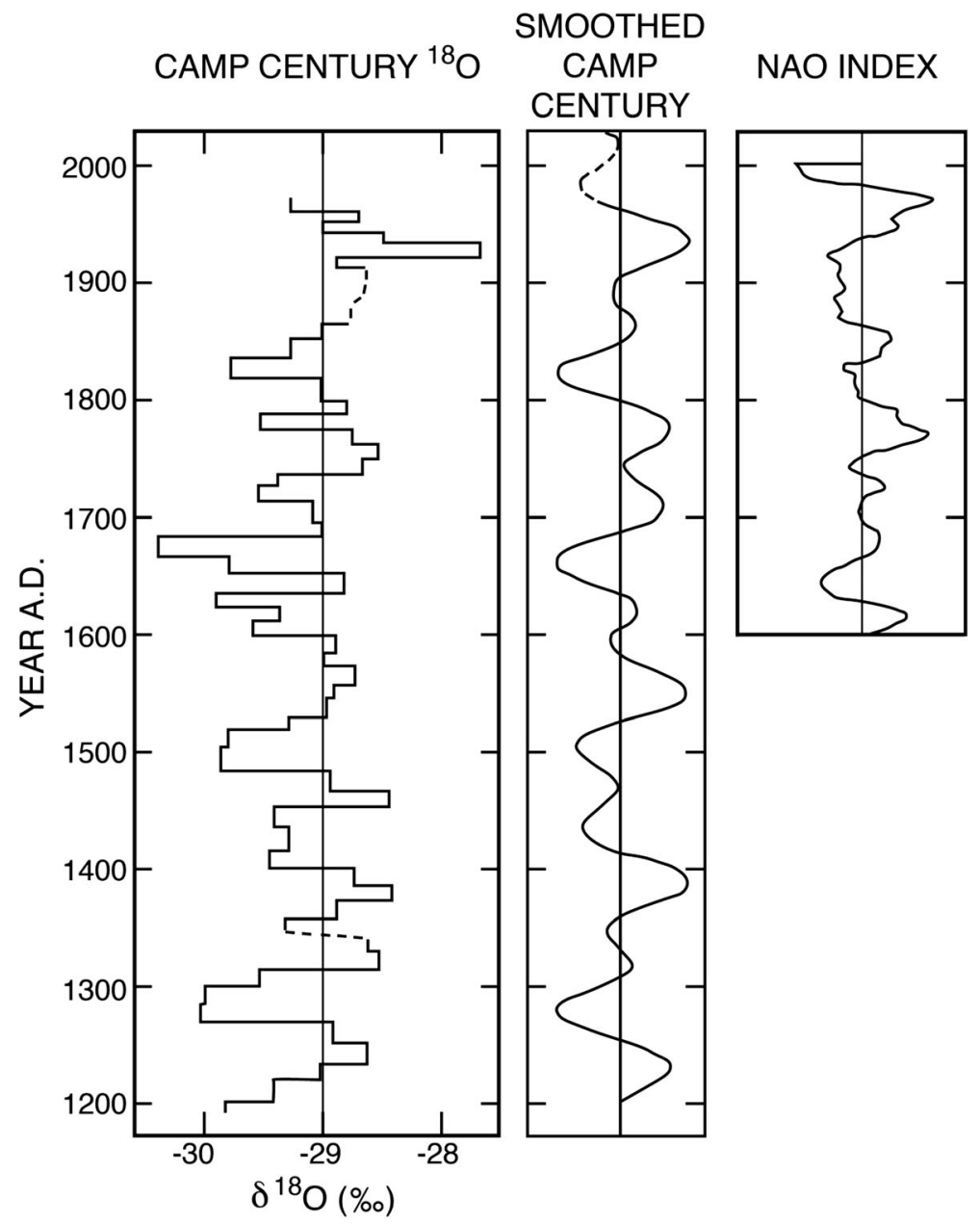

Fig. 2 The Camp Century Greenland ${ }^{18} \mathrm{O}$ record for the last 800 years (Dansgaard et al. 1971) compared with the record of the North Atlantic Oscillation for the last 400 years (Trouet et al. 2009). Also shown is Dansgaard's demonstration that 80 - and 180 -year cycles explain a sizable portion of the variance in his ${ }^{18} \mathrm{O}$ record 
Niño 3 region $\left(90^{\circ}\right.$ to $150^{\circ} \mathrm{W}, 5^{\circ} \mathrm{N}$ to $\left.5^{\circ} \mathrm{S}\right)$, Guilderson and Schrag (1998) concluded that the equatorial upwelling system underwent an important reorganization at that time. In both, seasonal minima became less pronounced (see Fig. 3), indicating that upwelling had weakened.

Although this change occurred at the time of an important El Niño event, the actual physics of what happened remains unclear. Perhaps in the new circulation regimen, the ocean absorbed less of the heat generated by the atmosphere's growing $\mathrm{CO}_{2}$ content.
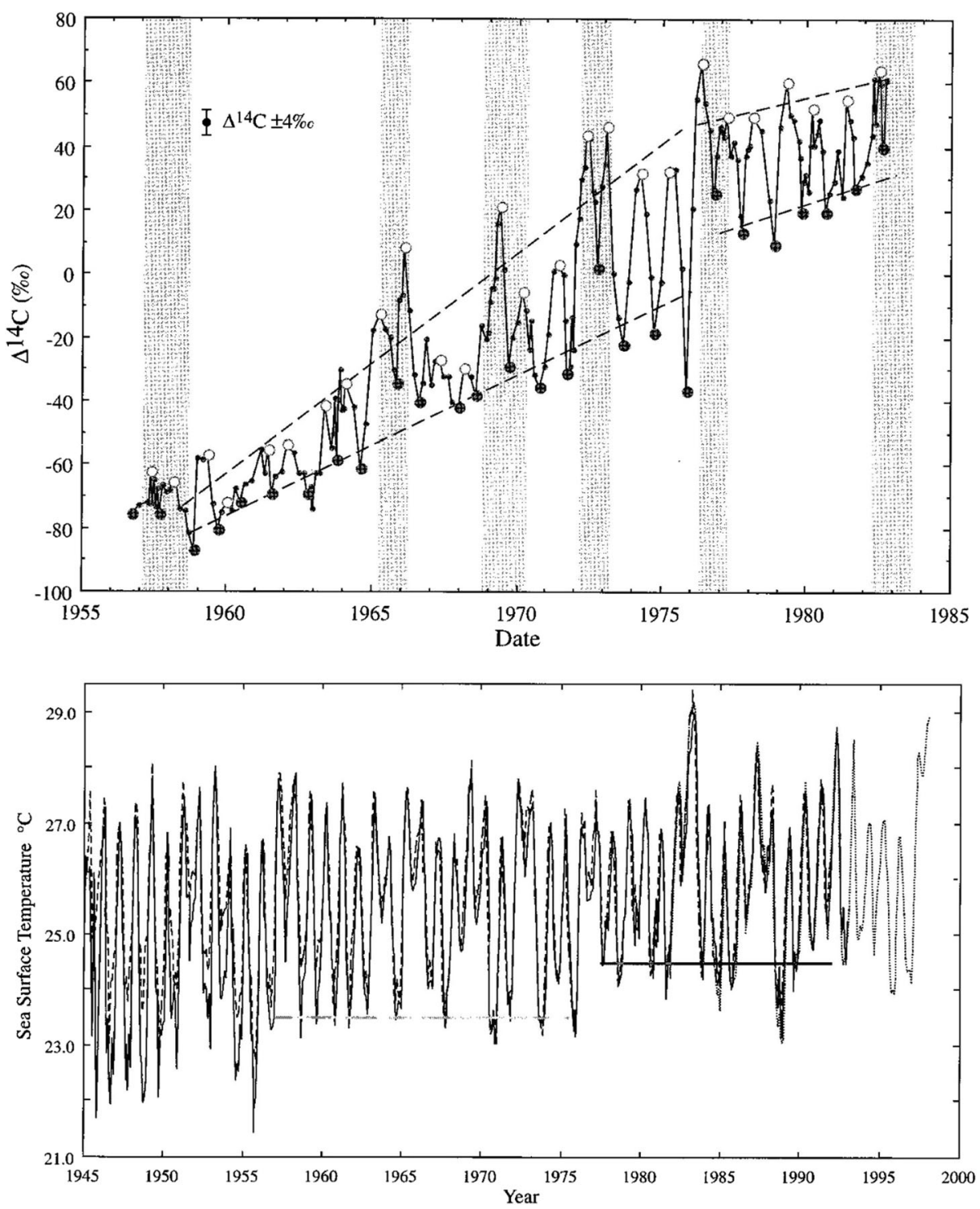

Fig. 3 Records of the seasonal variation of the ${ }^{14} \mathrm{C}$ to $\mathrm{C}$ ratio in a coral from the Galapagos Islands and that for the sea surface temperature in the Niño 3 area (Guilderson and Schrag 1998). Note that a change in amplitude occurs in 1976-1977 at the time of a major El Niño event (gray bar) 
This reorganization had repercussions elsewhere. McGowan et al. (2003) show that the frequency of warm events along the California Current underwent a dramatic increase in 1977 creating important biologic responses. Further, it also came at the time when the Pacific Decadal Oscillation (PDO) was undergoing an unusually large negative to positive transition (Henley et al. 2015) and a pronounced ${ }^{18} \mathrm{O}$ increase recorded in Tonga and Fiji corals (Linsley et al. 2015). It was also a time that a large increase in rainfall occurred in the Argentine Pampas (Troin et al. 2010).

\section{A signal and noise problem}

There was in hindsight another problem with my 1975 analysis. It had to do with magnitude of the noise in the temperature record. Between 1959 and 1975, $\mathrm{CO}_{2}$ rose from 315 to about $330 \mathrm{ppm}$. Based on the best match between the $\mathrm{CO}_{2}$ record and the temperature record (see Fig. 1), the temperature is expected to have risen by about $0.1{ }^{\circ} \mathrm{C}$. Considering that interannual temperature changes of up to about $0.3{ }^{\circ} \mathrm{C}$ occurred, it is not surprising that prior to 1975, no significant temperature increase could be identified. Also, it is possible that cooling caused by Anthropocene $\mathrm{CO}_{2}$ emissions had been counter balancing the $\mathrm{CO}_{2}$ warming.

\section{Why 1976-1977 warming remains important}

Those who choose not to accept that the warming produced by fossil fuel $\mathrm{CO}_{2}$ poses a serious threat, point to what they view as a cessation of warming during the first decade of this century (see Trenberth 2015). This observation has been used to strengthen the position of those who oppose tough legislation designed to reduce $\mathrm{CO}_{2}$ emissions. This plateau could be interpreted as an undoing of what happened in 1976-1977. Hence, it is of great importance to gain an understanding of these reorganizations and whether similar ones will punctuate the ongoing warming.

Open Access This article is distributed under the terms of the Creative Commons Attribution 4.0 International License (http://creativecommons.org/licenses/by/4.0/), which permits unrestricted use, distribution, and reproduction in any medium, provided you give appropriate credit to the original author(s) and the source, provide a link to the Creative Commons license, and indicate if changes were made.

\section{References}

Broecker WS (1975) Climatic change: are we on the brink of a pronounced global warming? Science 189:460463

Dansgaard W, Johnson SJ, Clausen HB, Langway CC Jr (1971) Climatic record revealed by Camp Century ice core. In: Turekian KK (ed) The late Cenozoic glacial ages. Yale University Press, New Haven, pp 37-56

Guilderson TP, Schrag DP (1998) Abrupt shift in subsurface temperatures in the Eastern Tropical Pacific associated with recent changes in El Niño. Science 281:240-243

Henley BJ, Gergis J, Karoly DJ, Power S, Kennedy J, Folland CK (2015) A tripole index for the interdecadal pacific oscillation. Clim Dyn. doi:10.1007/s00382-015-2525-1

Linsley BK, Wu HC, Dassié EP, Schrag DP (2015) Decadal changes in South Pacific sea surface temperatures and the relationship to the Pacific decadal oscillation and upper ocean heat content. Geophys Res Lett 42. doi: 10.1002/2015GL063045 
Malkin NR (1968) The retreat of the North American ice sheet and shifts in cyclone tracks. Sov Geogr 9. doi: 10.1080/00385417.1968.10771051

McGowan JA, Bograd SJ, Lynn RJ, Miller AJ (2003) The biological response to the 1977 regime shift in the California Current. Deep-Sea Res II 50:2567-2582

Mitchell JM Jr (1961) Recent secular changes of global temperature, solar variations, climatic change, and related geophysical problems. Ann N Y Acad Sci 95:235-250. doi:10.1111/j.1749-6632.1961.tb50036.x

Trenberth KE (2015) Has there been a hiatus? Internal climate variability masks climate-warming trends. Science 349:691-692

Troin M, Vallet-Coulomb C, Sylvestre F, Piovano E (2010) Hydrological modelling of a closed lake (Laguna Mar Chiquita, Argentina) in the context of 20th century climatic changes. J Hydrol 393:233-244

Trouet V, Esper J, Graham NE, Baker A, Scourse JD, Frank DC (2009) Persistent positive North Atlantic Oscillation mode dominated the medieval climate anomaly. Science 324:78-80

Vinther BM, Johnsen SJ, Andersen KK, Clausen HB, Hansen AW (2003) NAO signal recorded in the stable isotopes of Greenland ice cores. Geophys Res Lett 30:1387. doi:10.1029/2002GL016193

Young NE, Schweinsberg AD, Briner JP, Schaefer JM (2015) Glacier maxima in Baffin Bay during the Medieval Warm Period coeval with Norse settlement. Sci Adv 1:e1500806. doi:10.1126/sciadv.1500806 